\title{
Kaempferol Derivatives as Antiviral Drugs against the 3a Channel Protein of Coronavirus
}

Authors

Affiliations
Silvia Schwarz ${ }^{1}$, Daniel Sauter ${ }^{1,2}$, Kai Wang ${ }^{3}$, Ronghua Zhang ${ }^{3}$, Bing Sun ${ }^{3}$, Anastasia Karioti ${ }^{4}$, Anna Rita Bilia ${ }^{4}$, Thomas Efferth ${ }^{5}$, Wolfgang Schwarz ${ }^{1,2}$

The affiliations are listed at the end of the article
Key words

coronavirus

virus release

- ion channel

- kaempferol derivatives

- flavonoids

\section{Abstract \\ $\nabla$}

The protein coded by the open-reading-frame 3a of SARS coronavirus has been demonstrated to form a cation-selective channel that may become expressed in the infected cell. The activity of the channel is involved in the mechanism of virus release. Drugs that inhibit the ion channel can, therefore, inhibit virus release, and they could be a source for development of novel therapeutic antiviral agents. Various drugs found in Chinese herbs that are well known as anticancer agents also have an antiviral potency. Here we tested the flavonols kaempferol, kaempferol glycosides, and acylated kaempferol glucoside derivatives with respect to their potency to block the 3a channel. We used the Xenopus oocyte with a heterologously expressed 3a protein as a model system to test the efficacy of the flavonols. Some of these drugs turned out to be potent inhibitors of the 3a channel. The most effective one was the glycoside juglanin (carrying an arabinose residue) with an $\mathrm{IC}_{50}$ value of $2.3 \mu \mathrm{M}$ for inhibition of the 3a-mediated current. Kaempferol derivatives with rhamnose residue also seem to be quite effective. We suggest that viral ion channels, in general, may be a good target for the development of antiviral agents, and that, in particular, kaempferol glycosides are good candidates for 3a channel proteins of coronaviruses.

$\begin{array}{ll}\text { Abbreviations } \\ \text { CoV: } & \text { coronavirus } \\ \text { ORF: } & \text { open reading frame } \\ \text { ORi: } & \text { oocyte Ringer's } \\ \text { G-ORi: } & \text { ORi supplemented with gentamycin } \\ \text { NMR: } & \text { nuclear magnetic resonance } \\ \text { SARS: } & \text { severe acute respiratory syndrome } \\ \text { S1: } & \text { test solution without } \mathrm{Ba}^{2+} \\ \text { S2: } & \text { test solution with } 10 \mathrm{mM} \mathrm{Ba}^{2+}\end{array}$

received Sept. 14, 2013 revised Dec. 2, 2013 accepted Dec. 13, 2013

\section{Bibliography}

Dol http://dx.doi.org/ 10.1055/s-0033-1360277

Published online January 23 , 2014

Planta Med 2014; 80: 177-182

(c) Georg Thieme Verlag KG

Stuttgart · New York .

ISSN 0032-0943

\section{Correspondence}

Wolfgang Schwarz

Institute for Biophysics

JW-Goethe University

Max-von-Laue Str. 1

60438 Frankfurt a. M.

Germany

Phone: + 496979846401

wolfgang.schwarz@email.de

\section{Introduction}

$\nabla$

Various herbal antiviral drugs have been developed that interfere with the viral life cycle [1]. During the first appearance of SARS about $50 \%$ of the patients in mainland China were treated successfully with Chinese herbal medicine in addition to Western medicine [2,3].

Several viruses encode for ion-selective channels that become incorporated into the membrane of the infected cell [4-7]. Activation of such channels seems to be involved in the process of virus production and release [8-12]. Hence, inhibition of the ion channel activation will counteract virus production; this may allow the infected body to build up or strengthen its own immune system. The viral ion channel will, therefore, be a potential candidate for developing new antiviral drugs. The ORF 3a of SARS CoV encodes for an ion-permeable channel. We could previously demonstrate that micromolar concentrations of the anthraquinone emodin can inhibit the 3a channel activity with an $\mathrm{IC}_{50}$ value of only $20 \mu \mathrm{M}$ and also inhibit coronavirus release with a similar sensitivity from infected cells [13]. This indicates that the viral ion channel is an interesting target for antiviral drugs. Emodine as well as various flavonoids († Fig. 1) are well known to act as anticancer drugs [14, 15], but they were also discussed as antiviral drugs [16]. The flavonol kaempferol and its glycosides have been reported previously to have high antiviral activity [1], but effects on the intracellular events were favoured as an explanation [17, 18]. Here we investigated whether the flavonol kaempferol and kaempferol glycosides can block the 3a channel. In addition, we tested a number of other flavonoids ( Fig. 1). This manuscript ex- 


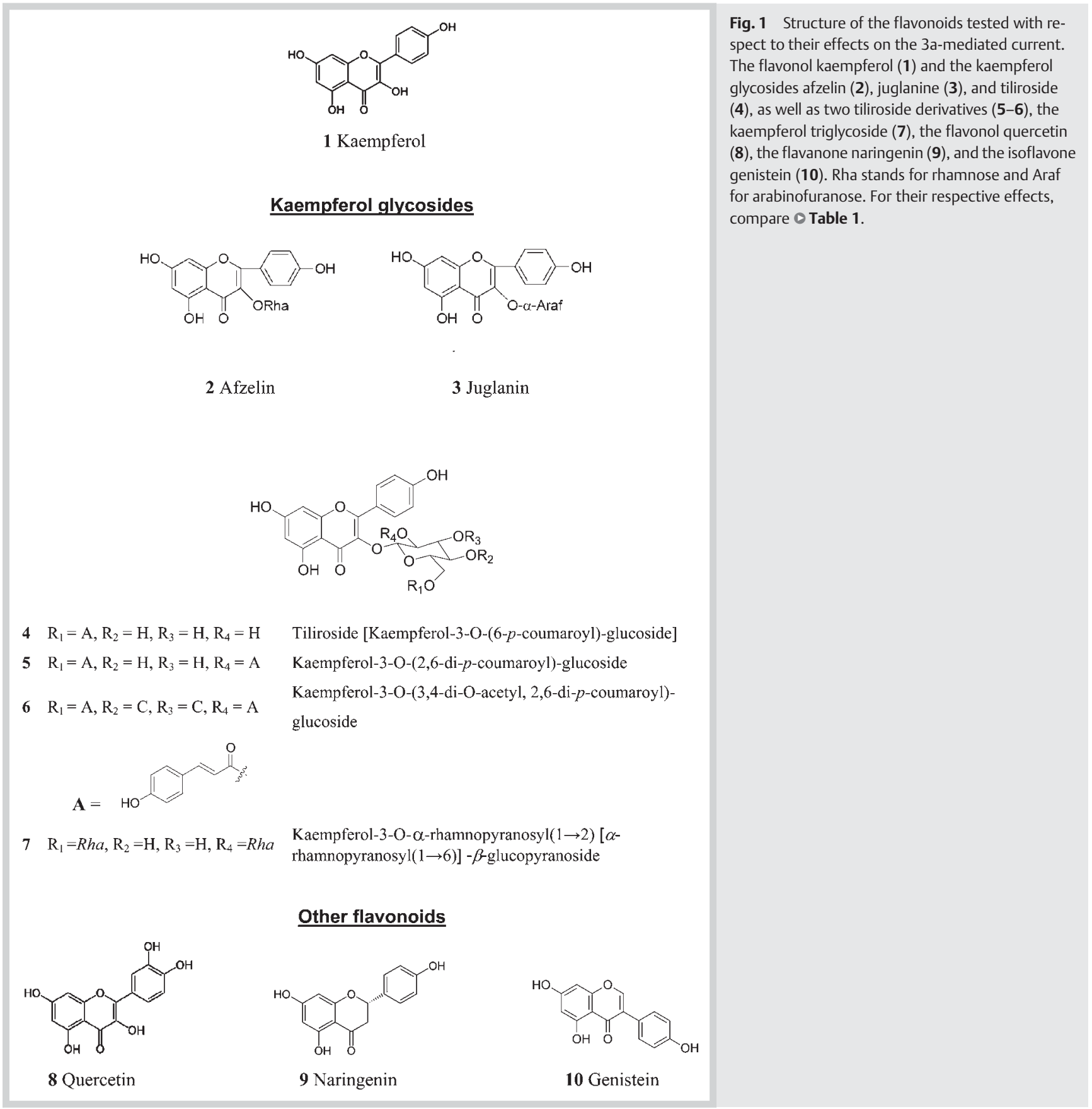

tends preliminary data [1] to investigate the role of this class of compounds in more detail.

\section{Results and Discussion}

$\nabla$

The flavonoids listed in $\bigcirc$ Table 1 are well known for their anticancer activity, but also various antiviral effects have been reported [18-20]. Here we investigated these drugs with respect to their efficacy to inhibit $\mathrm{Ba}^{2+}$-sensitive current. Fig. 2 a shows that $20 \mu \mathrm{M}$ kaempferol reduced endogenous $\mathrm{Ba}^{2+}$-sensitive current. At $-100 \mathrm{mV}$ the current was inhibited to $0.77 \pm 0.08$ $(p<0.01)$ of the control current in the absence of the drug. The degree of inhibition was independent of voltage.
In oocytes with expressed 3a protein, $\mathrm{Ba}^{2+}$-sensitive current was larger by a factor of about 3 to 5 than in control oocytes (compare - Fig. 2 a and b). Kaempferol also affected this additional 3a-mediated current component ( $\odot$ Fig. $\mathbf{2 b}$ ). After subtraction of the endogenous contribution ( Fig. $2 \mathrm{c}$ ), the current at $-100 \mathrm{mV}$ was reduced to $0.82 \pm 0.10$ of the current component in the absence of drug; this indicated that the endogenous and the 3a-mediated components exhibited similar sensitivity to kaempferol. This is in contrast to emodin which selectively inhibited the 3amediated current and at $20 \mu \mathrm{M}$ already produced more than $50 \%$ block (see [13]). The poor solubility of kaempferol in water did not allow testing a higher concentration for evaluation of an $\mathrm{IC}_{50}$ value. We therefore did not further follow up the effect of kaempferol, but rather screened for the effect of various other 
Table 1 Effect of drugs on a 3a-mediated current. Current remaining in the presence of the respective drug concentration is expressed as ratio compared to control current in the absence of drug; values are given as mean \pm SEM, based on $n$ measurements. The values were determined from currents at $-100 \mathrm{mV}$. Two of the kaempferol glycosides were, in addition to $20 \mu \mathrm{M}$, also tested at $40 \mu \mathrm{M}$. Statistical difference from the control value was determined by t-test and is given by the $p$ value; sns stands for statistically not significant $(p>0.2)$.

\begin{tabular}{|c|c|c|c|c|c|c|}
\hline & Drug & $\begin{array}{l}\text { Purity } \\
\text { (\%) }\end{array}$ & $\begin{array}{l}\text { Concentration } \\
(\mu \mathrm{M})\end{array}$ & $\begin{array}{l}\text { Remaining current } \\
\text { (relative to control) }\end{array}$ & $\mathbf{n}$ & $\mathbf{p}$ \\
\hline \multirow{7}{*}{$\begin{array}{l}\text { Kaempferol } \\
\text { glycosides }\end{array}$} & Kaempferol & $>97$ & 20 & $0.82 \pm 0.01$ & 7 & $<0.01$ \\
\hline & Juglanin & 98 & $\begin{array}{l}20 \\
10\end{array}$ & $\begin{array}{l}\text { Complete inhibition } \\
0.01 \pm 0.06\end{array}$ & 5 & $<0.01$ \\
\hline & Tiliroside & $>95$ & 20 & $0.48 \pm 0.09$ & 5 & $<0.01$ \\
\hline & Afzelin & 98 & 10 & $0.83 \pm 0.01$ & 5 & $<0.01$ \\
\hline & $\begin{array}{l}\text { Kaempferol-3-O-(2,6-di-p-coumaroyl)- } \\
\text { glucoside }\end{array}$ & $>95$ & $20(40)$ & No effect & 8 & sns \\
\hline & $\begin{array}{l}\text { Kaempferol-3-O-(3,4-diacetyl-2,6-di-p- } \\
\text { coumaroyl)-glucoside }\end{array}$ & $>95$ & $20(40)$ & No effect & 8 & sns \\
\hline & $\begin{array}{l}\text { Kaempferol-3-O- } \alpha \text {-rhamnopyranosyl } \\
(1 \rightarrow 2)[\alpha \text {-rhamnopyranosyl }(1 \rightarrow 6)]-\beta \text { - } \\
\text { glucopyranoside }\end{array}$ & $>95$ & 20 & $0.68 \pm 0.11$ & 4 & $<0.05$ \\
\hline \multirow{3}{*}{$\begin{array}{l}\text { Other } \\
\text { flavonoids }\end{array}$} & Quercetin & $>95$ & 10 & $0.91 \pm 0.10$ & 8 & sns \\
\hline & Naringenin & 98 & 20 & $0.93 \pm 0.05$ & 4 & sns \\
\hline & Genistein & $>96$ & 20 & $0.91 \pm 0.15$ & 5 & sns \\
\hline
\end{tabular}
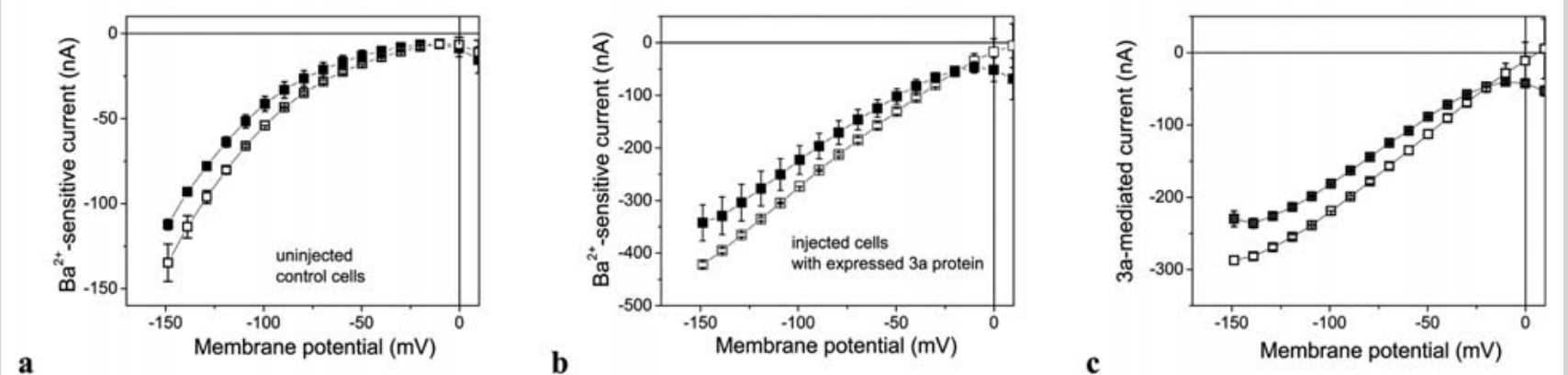

Fig. 2 Effect of kaempferol on current-voltage (IV) curves of $\mathrm{Ba}^{2+}$-sensitive current. Open squares describe the current-voltage dependencies in the ab-

currents, $\mathbf{b}$ currents of cells with heterologously expressed 3a protein, and sence and filled squares in the presence of $20 \mu \mathrm{M}$ kaempferol. a Endogenous c the 3a-protein-mediated current component (endogenous current subtracted). Data represent averages of $n=4$ to 7 experiments \pm SEM.

flavonoids. In particular, the glycosides ( Table 1) are watersoluble and in addition exhibit higher bioavailability [21].

In contrast to kaempferol, the tested kaempferol glycosides hardly affected $\mathrm{Ba}^{2+}$-sensitive endogenous current (for juglanin see, e.g., $\odot$ Fig. 3 a). In oocytes with an expressed 3a protein, stronger effects could be detected than with kaempferol (compare Table 1). Juglanin seemed to be the most potent kaempferol glycoside that gave complete inhibition at $20 \mu \mathrm{M}$; even $10 \mu \mathrm{M}$ produced nearly complete inhibition. Therefore, we focussed on this drug for a more detailed analysis. Fig. $\mathbf{3 b}$ illustrates the effect of two concentrations on the current-voltage dependencies of $\mathrm{Ba}^{2+}$-sensitive current in 3a protein-expressing oocytes. Already $2.5 \mu \mathrm{M}$ exhibited a significant inhibition. The dependence of the 3a-mediated current component on juglanin concentration is shown in $\mathbf{F i g . 3 c}$. The dashed line is a fit to the data of

$\mathrm{I}_{3 \mathrm{a}-\text { mediated }}=\frac{\mathrm{IC}_{50}^{\mathrm{n}}}{\mathrm{IC}_{50}^{\mathrm{n}}+[\text { juglanin }]^{\mathrm{n}}}$
At a concentration of about $2.3 \mu \mathrm{M}$ juglanin, $50 \%$ inhibition $\left(\mathrm{IC}_{50}\right)$ was obtained. Hence juglanin is about one order of magnitude more potent to block 3a-protein channel than emodine [13]. With an even higher $\mathrm{IC}_{50}$ value of $200 \mu \mathrm{M}$, emodine was shown to inhibit interaction between virus and host cell, which was considered to be a potent mechanism in herbal treatment of SARS [22]. The higher sensitivity of the 3a channel makes this protein an even more interesting target for drug development.

Two other tested kaempferol glycosides, tiliroside and afzelin, were less potent than juglanin but were nevertheless as effective as emodine. Tiliroside at $20 \mu \mathrm{M}$ produced a block to $0.48 \pm 0.09$ ( Table 1 and Fig. 3d); at the same concentration, juglanin completely blocked the 3a-mediated current ( $\odot$ Table 1 and Fig. $\mathbf{3 b}$ and d). A similar degree of inhibition as with $20 \mu \mathrm{M}$ kaempferol was obtained with only $10 \mu \mathrm{M}$ of afzelin (inhibition to $0.83 \pm$ 0.01 ) compared to the current in the absence of drug ( $\odot$ Table 1 and Fig. $\mathbf{3 d}$ ).

In a series of experiments, we also tested the acylated kaempferol derivatives kaempferol-3-0-(2,6-di-p-coumaroyl)-glucopyranoside and kaempferol-3-0-(3,4-diacetyl-2,6-di-p-coumaroyl)-glucoside, which all had an additional $p$-coumaroyl group (see 


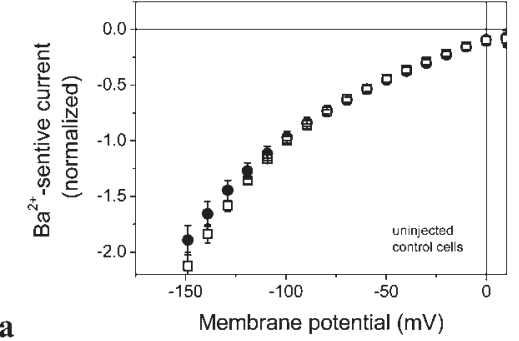

a

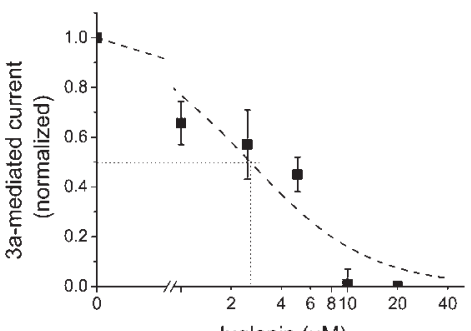

c

Juglanin $(\mu \mathrm{M})$
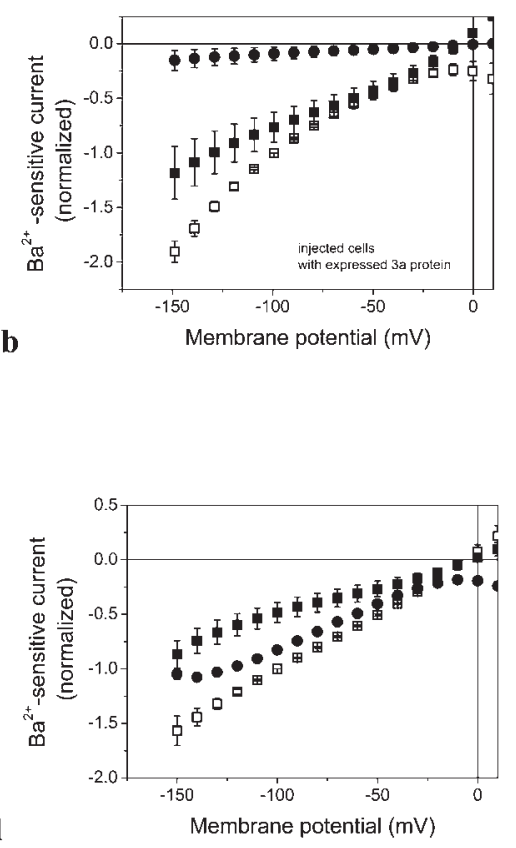

Fig. 3 Effect of kaempferol glycosides on $\mathrm{Ba}^{2+}$ sensitive and 3a-mediated current. Results in the absence of drug are given by open squares and in the presence of drug by filled symbols. a Effect of $10 \mu \mathrm{M}$ juglanin on current-voltage dependencies of $\mathrm{Ba}^{2+}$-sensitve current in control oocytes without a 3a protein. $\mathbf{b}$ Effect of 2.5 (filled squares) and $10 \mu \mathrm{M}$ (filled circles) juglanin on 3a-mediated current that was determined as the difference of $\mathrm{Ba}^{2+}$-sensitive current in a 3a-expressing cells. Data points represent averages from 4-7 experiments \pm SEM. $c$ Inhibition of a 3-mediated current at $-100 \mathrm{mV}$ by juglanin. The data points represent averages \pm SEM of 5-17 measurements. The dashed line is an approximation of equ. 1 to the data points with $n=1.2$ and $\mathrm{K}_{1 / 2}=2.3 \mu \mathrm{M}$. d Effect of $20 \mu \mathrm{M}$ tiliroside (squares) and $10 \mu \mathrm{M}$ afzelin (circles) on voltage dependence of a $\mathrm{Ba}^{2+}$-sensitive current in 3a-expressing cell. Data points represent averages from 4-7 experiments \pm SEM.
- Fig. 1). At $20 \mu \mathrm{M}$, both derivatives showed no effect on $\mathrm{Ba}^{2+}$-sensitive current. Even at concentrations up to $40 \mu \mathrm{M}$ (๑ Table 1), no significant inhibition could be detected. On the other hand, in a few orientating experiments, we found that the kaempferol triglycoside kaempferol-3-0- $\alpha$-rhamnopyranosyl $(1 \rightarrow 2)[\alpha$-rhamnopyranosyl $(1 \rightarrow 6)]-\beta$-glucopyranoside exhibited about $30 \%$ inhibition at $20 \mu \mathrm{M}$ ( Table 1 ); this was similar to the effect of afzelin which was also applied at $20 \mu \mathrm{M}$ in two of these experiments. Interestingly, both drugs are characterized by rhamnose residues (see $\bullet$ Fig. $\mathbf{1}$ ).

As another flavonol, we tested the effect of quercetin, which was reported to also act as an effective drug against virus infections including SARS CoV [23]. We found that the 3a-mediated current was not significantly affected by $10 \mu \mathrm{M}$ quercetin (see $\bigcirc$ Table 1 ); concentrations even up to $50 \mu \mathrm{M}$ hardly affected the 3a-mediated current. Also the quercetin derivative with an arabinofuranoside, avicularin (not shown), was without any effect.

The flavanone naringenin and the isoflavone genistein are also known for their antiviral potency (see, e.g., [24-26]), but neither naringenin nor genistein exhibited any significant modulation of the 3a-mediated current (see 0 Table 1).

Though the flavonols quercetin and avicularin, the flavanone naringenin, and the isoflavone genistein do not affect the activity of the 3 a protein, the flavonol kaempferol exhibits a clear inhibition of the 3a-mediated current; the kaempferol glycosides are even more potent inhibitors thus suggesting an importance of sugar residues. The most potent drug was the kaempferol glycoside juglanin with an arabinose residue. Interestingly, the kaempferol glycoside afzelin and the triglycoside with rhamnose residues seem also to be quite effective. In addition to the higher effectivity of the flavonoid glycosides to inhibit the 3a protein ion channel, they show higher solubility in water with higher bioactivity [19,21].

Though flavonoid glycosides may be absorbed in the small intestine, biodegradation will limit their therapeutical application, and levels in plasma are probably below $1 \mu \mathrm{M}$ [21]. An important task for developing new antiviral drugs will therefore have to fo- cus on improving bioactivity [27]; several strategies have been tackled for increasing bioavailability including drug delivery and metabolic stability (compare $[19,21,27,28]$ ).

Activity of the 3a protein results in ion channel gating which allows small cations to cross the membrane. Although the channel shows selectivity for $\mathrm{K}^{+}$, also $\mathrm{Na}^{+}$can penetrate with slightly lower permeability [11]. As a consequence, activity of channel openings will lead to membrane depolarization, and activation of Ltype $\mathrm{Ca}^{2+}$ channels [29] to an elevation of intracellular $\mathrm{Ca}^{2+}[30]$. This could account for the 3a-protein-dependent release of $\mathrm{CoV}$ from infected cells via exocytosis. Indeed, inhibition of 3a channel activity blocks virus release; this could be demonstrated by suppression of 3a expression as well as pharmacological inhibition of the 3 a channel $[11,13]$. This reduction in virus production offers the body the chance to adjust its immune system to counteract the viral attack. Inhibition of ion channels encoded by other viruses could also be demonstrated to inhibit the respective virus production [31-33].

As a conclusion, we suggest that emodin and kaempferol could form the basis for the development of new antiviral drugs with higher bioavailability. In particular, the glycosides of kaempferol seem to be highly potent candidates for development as anti-coronaviral agents. The fact that these drugs not only block the 3a channel, thus counteracting virus production, but that they also interfere with other steps of the viral life cycle [20] emphasises the importance of multi-target drugs.

\section{Materials and Methods}

$\nabla$

\section{Expression of 3a protein in Xenopus oocytes}

To investigate effects of kaempferol and its derivatives on the 3a protein of SARS-CoV, we used the Xenopus oocyte for heterologous expression and applied voltage-clamp techniques (for details see $[11,13])$. Females of the clawed toad Xenopus laevis (Maosheng Bio-Technology Com.) were anaesthetized with tricane ( $1 \mathrm{~g} / \mathrm{L} \mathrm{H}_{2} \mathrm{O}, \mathrm{MS} 222$; Sandoz) or in ice water. Parts of the ova- 
ry were removed and treated with 0.3 units/mL Liberase (Roche) or with $1 \mathrm{mg} / \mathrm{mL}$ Collagenase (Sigma) for 3 to $4 \mathrm{~h}$ to remove enveloping tissue and to obtain isolated oocytes. The entire procedure follows standard protocols including care of laboratory animals that have been established according to German Animal Protection Law. For expression of 3a protein, oocytes of stage $\mathrm{V}$ or VI [34] were selected and injected with 20 or 30 ng cRNA for 3a protein (for details see [11]) (at $1 \mathrm{ng} / \mathrm{nL}$ ) two to three days before the experiments; uninjected oocytes served as controls. The cells were stored for 2 days at $19^{\circ} \mathrm{C}$ in oocyte Ringer's-like solution (G-ORi, see solutions). Experiments were performed at room temperature $\left(24-26^{\circ} \mathrm{C}\right)$.

\section{Solutions}

Standard ORi solution contained: $90 \mathrm{mM} \mathrm{NaCl}, 2 \mathrm{mM} \mathrm{KCl}, 2 \mathrm{mM}$ $\mathrm{CaCl}_{2}$, and $5 \mathrm{mM}$ Hepes (adjusted to $\mathrm{pH} 7.4$ with Tris). For cell incubation, the ORi was supplemented with $70 \mu \mathrm{g} / \mathrm{L}$ gentamycin (G-ORi).

Since the 3a protein channel showed high permeability to $\mathrm{K}^{+}[11]$, the test solution without $\mathrm{Ba}^{2+}$ (S1) contained: $100 \mathrm{mM} \mathrm{KCl,} 2 \mathrm{mM}$ $\mathrm{MgCl}_{2}$, and $5 \mathrm{mM}$ Hepes ( $\mathrm{pH} 7.4$ ); because the Xenopus oocytes express endogenous $\mathrm{Ca}^{2+}$-activated $\mathrm{K}^{+}$and $\mathrm{Cl}^{-}$channels, $\mathrm{Ca}^{2+}$ was omitted from the bath solutions (but replaced by $\mathrm{Mg}^{2+}$ ) to reduce these background currents. Test solution S2 contained $10 \mathrm{mM}$ $\mathrm{BaCl}_{2}$ in addition. The change in osmolarity due to addition of $\mathrm{BaCl}_{2}$ did not affect the membrane currents. The difference between the current measured in S1 and S2 was considered as the $\mathrm{Ba}^{2+}$-sensitive current component. Both solutions, S1 and S2, contained some DMSO (see below).

All stock solutions of drugs were made up in DMSO. Kaempferol was purchased from Sigma-Aldrich; two probes of the kaempferol glycosides (juglanin, kaempferol-3-O- $\alpha$-L-arabinofuranoside, and afzelin, kaempferol-3-O- $\alpha$-L-rhamnoside) were kindly provided by Prof. X. Hao and Dr. Y. Wang, Kunming, China, or bought from BioBioPHa.

Kaempferol acylated glucosides were previously isolated from polar extracts from the leaves of the plant Quercus ilex L. [35]; the kaempferol triglycoside was an isolate from Viola odorata $\mathrm{L}$. [36]. Isolation was carried out mainly by column chromatography on Sephadex LH-20 and silica gel. The structure of the compounds was established by NMR experiments. The purity was checked by NMR and high-performance liquid chromatography with diode array detector and was over 95\%. Quercetin and naringenin were purchased from Sigma-Aldrich, and genistein from Sinopharm Chemical Reagent Co., Ltd. The purities of all drugs are listed in 0 Table 1.

\section{Voltage-clamp experiments}

We applied conventional two-electrode voltage clamp using Turbo TEC-03 with CellWorks software (NPI Electronic) to measure the current mediated by SARS-3a protein. This method allowed directly monitoring modulations of the ion channel function under various conditions including inhibition by drugs. Previously, we had successfully applied this method to show that emodin (purity $>95 \%$ ) inhibits ion flow through the 3a protein ion channel [13]. To determine steady-state current-voltage dependencies (IV curves), membrane currents were averaged during the last $20 \mathrm{~ms}$ of $200 \mathrm{~ms}$, rectangular voltage pulses from -150 to $+30 \mathrm{mV}$ in $10-\mathrm{mV}$ increments; the pulses were applied from a holding potential of $-60 \mathrm{mV}$. To avoid changes at the bath electrodes due to changes in $\mathrm{Cl}^{-}$activity, the electrodes were uncoupled from the bath via ORi-filled channels.
Current mediated by the 3a protein can be blocked by $\mathrm{Ba}^{2+}[11]$. Therefore, we determined $\mathrm{Ba}^{2+}$-sensitive current as the difference of steady-state current in the presence and absence of $10 \mathrm{mM}$ $\mathrm{BaCl}_{2}$ (see Solutions). Since oocytes which did not express 3a protein also exhibited some $\mathrm{Ba}^{2+}$-sensitive current contribution, this endogenous component was determined in uninjected control cells and used for subtraction from total $\mathrm{Ba}^{2+}$-sensitive current of the injected oocytes from the same batch. The difference was considered to represent 3a-mediated current.

To correct for possible drift with time, $\mathrm{Ba}^{2+}$-sensitive current was calculated according to:

$\mathrm{I}_{\text {Ba-sensitive }}=\frac{\mathrm{IS} 1_{\text {before }}-\mathrm{IS} 1_{\text {after }}}{2}-\mathrm{IS} 2$

or

$\mathrm{I}_{\text {Ba-sensitive }}=\mathrm{IS} 1-\frac{\mathrm{IS} 2_{\text {before }}-\mathrm{IS} 2_{\text {after }}}{2}$

IS1 and IS2 stand for current measurements in the absence and presence of the $\mathrm{Ba}^{2+}$, respectively, the subscripts before and ${ }_{\mathrm{after}}$ refer to measurements before and after the measurement with the respective other solution. For a typical experiment, either of the following sequences of solutions was used for perfusing the chamber with the oocyte:

$\mathrm{S} 1 \rightarrow \mathrm{S} 2 \rightarrow \mathrm{S} 1 \rightarrow \mathrm{S} 1+\rightarrow \mathrm{S} 2+\rightarrow \mathrm{S} 1+\rightarrow \mathrm{S} 1 \rightarrow \mathrm{S} 2 \rightarrow \mathrm{S} 1$

$\mathrm{S} 2 \rightarrow \mathrm{S} 1 \rightarrow \mathrm{S} 2 \rightarrow \mathrm{S} 2+\rightarrow \mathrm{S} 1+\rightarrow \mathrm{S} 2+\rightarrow \mathrm{S} 2 \rightarrow \mathrm{S} 1 \rightarrow \mathrm{S} 2$

The + sign indicates solutions with the respective drug.

\section{Acknowledgements}

$\nabla$

We gratefully acknowledge the technical assistance from Huiming Du during the various steps of this project. SS, DS, and WS thank Prof. Gu Quanbao for helpful discussions. The work was supported by the National Basic Research Program of China (973 Program, 2012CB518502). We also gratefully acknowledge the support from Green Valley Holding Co, Shanghai.

\section{Conflict of Interest \\ $\nabla$}

All authors declare that there are no conflicts of interest.

Affiliations

1 Shanghai Research Center for Acupuncture \& Meridians, Shanghai, China

${ }^{2}$ Institute for Biophysics, JW-Goethe-University, Frankfurt a. M., Germany

${ }^{3}$ Key Laboratory of Molecular Virology \& Immunology, Institut Pasteur of

Shanghai, Shanghai Chinese Academy of Sciences, Shanghai, China

${ }^{4}$ Department of Chemistry, Building of Pharmaceutical Sciences, University of Florence, Sesto Fiorentino (FI), Italy

${ }^{5}$ Institute for Pharmacology and Biochemistry, J-Gutenberg University, Mainz, Germany

\section{References}

1 Schwarz S, Sauter D, Lu W, Wang K, Sun B, Efferth T, Schwarz W. Coronaviral ion channels as target for Chinese herbal medicine. Forum Immunopathol Dis Ther 2012; 3: 1-13

2 Zhang MM, Liu XM, He L. Effect of integrated traditional Chinese and Western medicine on SARS: A review of clinical evidence. World J Gastroenterol 2004; 10: 3500-3505 
3 Liu XM, Zhang MM, He L, Li YP, Kang YK. Chinese herbs combined with Western medicine for severe acute respiratory syndrome (SARS). Cochrane Database Syst Rev 2006; 1: CD004882

4 Fischer WB, Thiel G, Fink RHA. Viral membrane proteins. Eur Biophys J 2010; 39: 1041-1042

5 Krüger J, Fischer WB. Assembly of viral membrane proteins. J Chem Theor Comput 2009; 5: 2503-2513

6 Wang K, Xie S, Sun B. Viral proteins function as ion channels. Biochim Biophys Acta 2011; 1808: 510-515

7 Fischer WB, Wang YT, Schindler C, Chen CY. Mechanism of function of viral channel protein and implications for drug development. In: Kwang WJ, editor. International Review of Cell and Molecular Biology, Volume 294. Burlington: Elsevier Inc./Academic Press; 2012: 259-321

8 Liang X, Li ZY. Ion channels as antivirus targets. Virol Sin 2010; 25 : 267-280

9 Kelly ML, Cook J-A, Brown-Augsburger P, Heinz BA, Smith MC, Pinto LH. Demonstrating the intrinsic ion channel activity of virally encoded proteins. FEBS Lett 2003; 552: 61-67

10 Montal M. Structure-function correlates of $\mathrm{Vpu}$, a membrane protein of HIV-1. FEBS Lett 2003; 552: 47-53

11 Lu W, Zheng BJ, Xu K, Schwarz W, Du LY, Wong CKL, Chen JD, Duan SM, Deubel $V$, Sun $B$. Severe acute respiratory syndrome-associated coronavirus 3a protein forms an ion channel and modulates virus release. Proc Natl Acad Sci USA 2006; 103: 12540-12545

12 Schwarz S, Sauter D, Lu W, Wang K, Sun B, Efferth T, Schwarz W. Coronaviral ion channels as target for Chinese herbal medicine. Forum Immunopathol Dis Ther 2012; 3: 1-13

13 Schwarz S, Wang K, Yu W, Sun B, Schwarz W. Emodin inhibits current through SARS-associated coronavirus 3a protein. Antivir Res 2011; 90: 64-69

14 Tan W, Lu J, Huang M, Li Y, Chen M, Wu G, Gong J, Zhong Z, Xu Z, Dang Y, Guo J, Chen X, Wang Y. Anti-cancer natural products isolated from Chinese medicinal herbs. Chin Med 2011; 6: 27

15 Lown JW. Anthracycline and anthraquinone anticancer agents: Current status and recent developments. Pharmacol Ther 1993; 60: 185-214

16 Naithani R, Huma LC, Holland LE, Shukla D, McCormick DL, Mehta RG, Moriarty RM. Antiviral activity of phytochemicals: A comprehensive review. Minirev Med Chem 2008; 8: 1106-1133

17 Lyu S-Y, Rhim J-Y, Park $W$-B. Antiherpetic activities of flavonoids against herpes simplex virus type 1 (HSV-1) and type 2 (SV-2) in vitro. Arch Pharm Res 2005; 28: 1293-1301

18 Mitrocotsa D, Mitaku S, Axarlis S, Harvala C, Malamas M. Evaluation of the antiviral activity of kaempferol and its glycosides against human cytomegalovirus. Planta Med 2000; 66: 377-379

19 Nijveldt RJ, van Nood E, van Hoorn DEC, Boelens PG, van Norren K, Leeuwen PAM. Flavonoids: a review of probable mechanisms of action and potential applications. Am J Clin Nutr 2001; 74: 418-425

$20 \mathrm{Kaul}$ TN, Middleton E, Ogra PL. Antiviral effect of flavonoids on human viruses. J Med Virol 1985; 15: 71-79
21 Hollman PCH. Absorption, bioavailability, and metabolism of flavonoids. Pharm Biol 2004; 42: 74-83

22 Ho TW, Wu SL, Chen JC, Li CC, Hsiang CY. Emodin blocks the SARS coronavirus spike protein and angiotensin-converting enzyme 2 interaction. Antivir Res 2007; 74: 92-101

23 Chen L, Li J, Luo C, Liu H, Xu W, Chen G, Liew OW, Zhu W, Push CM, Shen X, Jiang $H$. Binding interaction of quercetin-3- $\beta$-galactoside and its synthetic derivatives with SARS-CoV $3 \mathrm{CL}^{\text {pro: }}$ Structure activity relationship studies reveal salient pharmacophore features. Bioorg Med Chem 2006; 14: 8295-8306

24 Lyu SY, Rhim JY, Park WB. Antiherpetic activities of flavonoids against herpes simplex virus type 1 (HSV-1) and type 2 (HSV-2) in vitro. Arch Pharm Res 2005; 28: 1293-1301

25 Liu AL, Wang HD, Lee SMY, Wang YT, Du GH. Structure-activity relationship of flavonoids as influenza virus neuraminidase inhibitors and their in vitro anti-viral activities. Bioorg Med Chem 2008; 16: 71417147

26 Evers DL, Chao CF, Wang X, Zhang Z, Huong SM, Huang ES. Human cytomegalovirus-inhibitory flavonoids: Studies on antiviral activity and mechanism of action. Antiviral Res 2005; 68: 124-134

27 Thilakarathna SH, Rupasinghe HPV. Flavonoid bioavailability and attempts for bioavailability enhancement. Nutrients 2013; 5: 3387

28 Walle T. Absorption and metabolism of flavonoids. Free Radic Biol Med 2004; 36: 829-837

$29 \mathrm{Lu} \mathrm{W}, \mathrm{Xu} \mathrm{K}$, Sun B. SARS accessory proteins ORF3a and 9b and their functional analysis. In: Lal SK, editor. Molecular biology of the SARScoronavirus. Berlin, Heidelberg: Springer; 2010: 167-175

30 Zhou Y, Frey TK, Yang JJ. Viral calciomics: Interplays between Ca2+ and virus. Cell Calcium 2009; 46: 1-17

31 Wilson L, Gage P, Ewart G. Hexamethylene amiloride blocks E protein ion channels and inhibits coronavirus replication. Virology 2006; 353: 294-306

32 Luscombe CA, Huang ZH, Murray MG, Miller M, Ilkinson J, Ewart GD. A novel Hepatitis $C$ virus p 7 ion channel inhibitor, BIT225, inhibits bovine viral diarrhea virus in vitro and shows synergism with recombinant interferon- $\alpha$-2b and nucleoside analogues. Antivir Res 2010; 86: 144-153

33 Xie SQ Wang K, Yu W, Lu W, Xu K, Wang J, Ye B, Schwarz W, Jin Q, Sun B. DIDS blocks a chloride-dependent current that is mediated by the $2 \mathrm{~B}$ protein of enterovirus 71. Cell Res 2011; 21: 1271-1275

34 Dumont JN. Oogenesis in "Xenopus laevis" (Daudin): I. Stages of oocyte development in laboratory maintained animals. J Morphol 1972; 136: 153-180

35 Karioti A, Bilia AR, Skaltsa H. Quercus ilex L.: A rich source of polyacylated flavonoid glucosides. Food Chem 2010; 123: 131-142

36 Karioti A, Furlan C, Vincieri FF, Bilia AR. Analysis of the constituents and quality control of Viola odorata aqueous preparations by HPLC-DAD and HPLC-ESI-MS. Anal Bioanal Chem 2011; 399: 1715-1723 